\title{
SEASONAL DYNAMICS OF MICROZOOPLANKTON IN THE SÃO SEBASTIÃO CHANNEL (SP, BRAZIL)
}

\author{
ESKINAZI-SANT'ANNA, E. M. ${ }^{1}$ and BJÖRNBERG, T. K. S. ${ }^{2}$ \\ ${ }^{1}$ Departamento de Oceanografia e Limnologia, Centro de Biociências, Universidade Federal do Rio Grande do Norte, \\ Via Costeira, s/n, Praia de Mãe Luiza, CEP 59014-100, Natal, RN, Brazil \\ ${ }^{2}$ Instituto de Biociências, Centro de Biologia Marinha, Universidade de São Paulo, \\ C. P. 83, CEP 11600-970, São Sebastião, SP, Brazil \\ Correspondence to: Eneida Maria Eskinazi Sant'Anna, Departamento de Oceanografia e Limnologia, \\ Centro de Biociências, Universidade Federal do Rio Grande do Norte, Via Costeira, s/n, Praia de Mãe Luiza, \\ CEP 59014-100, Natal, RN, Brazil, e-mail: eskinazi@icb.ufmg.br; eskinazi@ufrnet.br \\ Received February 6, 2004 - Accepted March 1, 2005 - Distributed February 28, 2006
}

(With 6 figures)

\begin{abstract}
The qualitative composition, numerical abundance and seasonal distribution of microzooplankton in the São Sebastião Channel were studied in different seasonal periods. Data are presented for 43 Protozoa, 4 rotifer and 30 copepod nauplii specimens. Tintinnids represented the most abundant group within the microzooplankton community, with 31 species recorded, among which Amphorellopsis acuta, Codonellopsis morchella, Eutintinnus tenuis, Favella ehrenbergii, Leprotintinnus nodqvisti, Tintinnopsis buetschlil, T. lobiancoi and T. radix stood out, followed in abundance by copepod nauplii. Our findings indicated that water masses play a fundamental role in the seasonal composition of microzooplankton assemblages in the São Sebastião Channel.
\end{abstract}

Keywords: microzooplankton, composition, dynamics, Brazil.

\section{RESUMO}

\section{Dinâmica sazonal do microzooplâncton no Canal de São Sebastião (SP, Brasil)}

Foram estudadas a composição qualitativa, a abundância numérica e a distribuição sazonal do microzooplâncton no Canal de São Sebastião, em diferentes períodos sazonais. São apresentados resultados para 43 táxons de Protozoa, 4 de rotíferos e 30 de náuplios de copépodos. Os tintinídeos representaram o grupo mais abundante do microzooplâncton, com 31 espécies registradas, destacando-se Amphorellopsis acuta, Codonellopsis morchella, Eutintinnus tenuis, Favella ehrenbergii, Leprotintinnus nodqvisti, Tintinnopsis buetschlil, T. lobiancoi e T. radix, além de náuplios de copépodos. Os resultados obtidos indicam que as massas de água desempenham um papel crucial na composição sazonal das assembléias microzooplanctônicas do canal de São Sebastião.

Palavras-chave: microzooplâncton, composição, dinâmica, Brasil.

\section{INTRODUCTION}

The ecological importance of microzooplankton in the pelagic food webs of the world's oceans has long been recognized. These organisms often constitute a significant component of the plankton community in many marine environments (Relevante et al., 1985, Burkill et al., 1987).
Microzooplankton has long been thought to be a major consumer of smaller particles unavailable to meso- and macrozooplankton (Linley et al., 1983, Gifford, 1991). Microzooplankton also acts as a significant food source for a variety of invertebrate and vertebrate predators (Fenchel, 
1987; Stoecker \& Egloff, 1987; Godhantaraman 2001, 2002; Godhantaraman \& Uye, 2001). Thus, microzooplankton is an important link in transferring pico- and nanoplankton production to higher trophic levels.

Despite abundant evidence of the importance of microzooplankton in marine pelagic food webs, little is known about their density composition and temporal distribution in Brazilian coastal waters (Pompeu, 1998). Most studies undertaken to date have approached mainly the aspects of taxonomy and biogeography of the species (Balech, 1971; Sassi \& Melo, 1989; Nogueira-Paranhos, 1990; Fernandes, $2004 \mathrm{a}$ and b). The present study purported to examine microzooplankton abundance and temporal dynamics in the São Sebastião Channel (SSC), thereby contributing toward an understanding of how the channel's oceanographic features influence the patterns observed.

\section{STUDY AREA}

The São Sebastião Channel (SSC) lies along the northeast coast of the state of São Paulo (from $23^{\circ} 41^{\prime} \mathrm{S}-45^{\circ} 10^{\prime} \mathrm{W}$ to $23^{\circ} 53^{\prime} \mathrm{S}-45^{\circ} 30^{\prime} \mathrm{W}$ ) and is delimited by the slopes of the Serra do Mar on the west and by São Sebastião Island on the east. The funnel-shaped channel describes a broad curve along its $25 \mathrm{Km}$ of extension, with the narrowest portion ( $2 \mathrm{Km}$ wide) in the center, broadening to $7.2 \mathrm{Km}$ at the southern entrance and to $5.6 \mathrm{Km}$ at the northern entrance. The depths along this longitudinal axis range from around $20 \mathrm{~m}$ at the entrances to up to $50 \mathrm{~m}$ in the inner portion. Water temperature and salinity were found to vary annually between $18-25^{\circ} \mathrm{C}$ and 35-37\%o, respectively. Total chlorophyll (chl- $a+$ phaeopigments) averaged $4.3 \mathrm{mg}$ Chl- $a \mathrm{~m}^{-3}$ and varied annually from 0.16 to $6.42 \mathrm{mg}$ Chl $-a \mathrm{~m}^{-3}$ (Gianesella-Galvão et al., 1997). The temperature in the region is moderately high year round, with a monthly average ranging from $19.5^{\circ} \mathrm{C}$ in winter to $25.5^{\circ} \mathrm{C}$ in summer. Annual precipitation oscillates between 1,500 and $2,000 \mathrm{~mm}$, with the dry period occurring from June to August and the rainy period from January to March.

\section{MATERIAL AND METHODS}

Sampling was carried out every three months, from January 1996 to July 1997 and in July 1998 and
January 1999, at two stations in the SSC (Fig. 1). Sampling point I (P I) was located in the middle of the channel and point II (P II) in an inner portion of the channel influenced by coastal drainage, mainly from the waters of the Outeiro Stream. Surface water samples for microzooplankton analyses were collected with a Van Dorn bottle (10 L). Subsamples $(300 \mathrm{~mL})$ were immediately preserved in $1 \%$ formalin plus glutaraldehyde seawater solution and kept refrigerated until microscopic examination.

Organisms were counted under an inverted microscope at magnifications of 100x and 400x. Microzooplankton was assigned to eight taxonomic groups, i.e., Heliozoa, Radiolaria, Testacea, Foraminifera, Tintinnida, naked ciliates (according to Souto, 1981; Linn et al., 1991; Alder, 1999; Boltovskoy, 1999; Petz, 1999), Rotifera (Koste, 1978) and copepod nauplii (Björnberg et al., 1994). To record the thermohaline characteristics of the water column, samples were collected at 2-m intervals from the surface to the bottom using Van Dorn bottle. Water temperature measurements were made with the help of an ordinary thermometer. Records of salinity were obtained using an optical refractometer.

\section{RESULTS}

\section{Environmental variables}

Fig. 2 shows seasonal and spatial variations in temperature and salinity. Water temperature ranged from $18{ }^{\circ} \mathrm{C}$ in Jul 97 to $28{ }^{\circ} \mathrm{C}$ in Jan 96, Jan 97 and Jan 99. Thermocline was recorded frequently at 10 meters at P I and seven meters at P II. Salinity, which varied from 31 to $36 \%$, was much lower at $\mathrm{P}$ II. The lowest salinity values were recorded in January due to the local rainy season. P I and P II showed an increasing trend for differences in both surface salinity and vertical salinity. The annual average salinity at the surface was $34 \%$ at P I and $31 \%$ at P II.

\section{Taxonomic composition, density and distribution of microzooplankton}

Fig. 3 shows the temporal change in microzooplankton density at each sampling station. Microzooplankton density varied markedly with seasonal periods, reaching values of 5.25 org. $\mathrm{L}^{-1}$ (P I - Jan 99) to 101.32 org.L.- (P I - Jan 96). Two seasonal microzooplankton density peaks were 


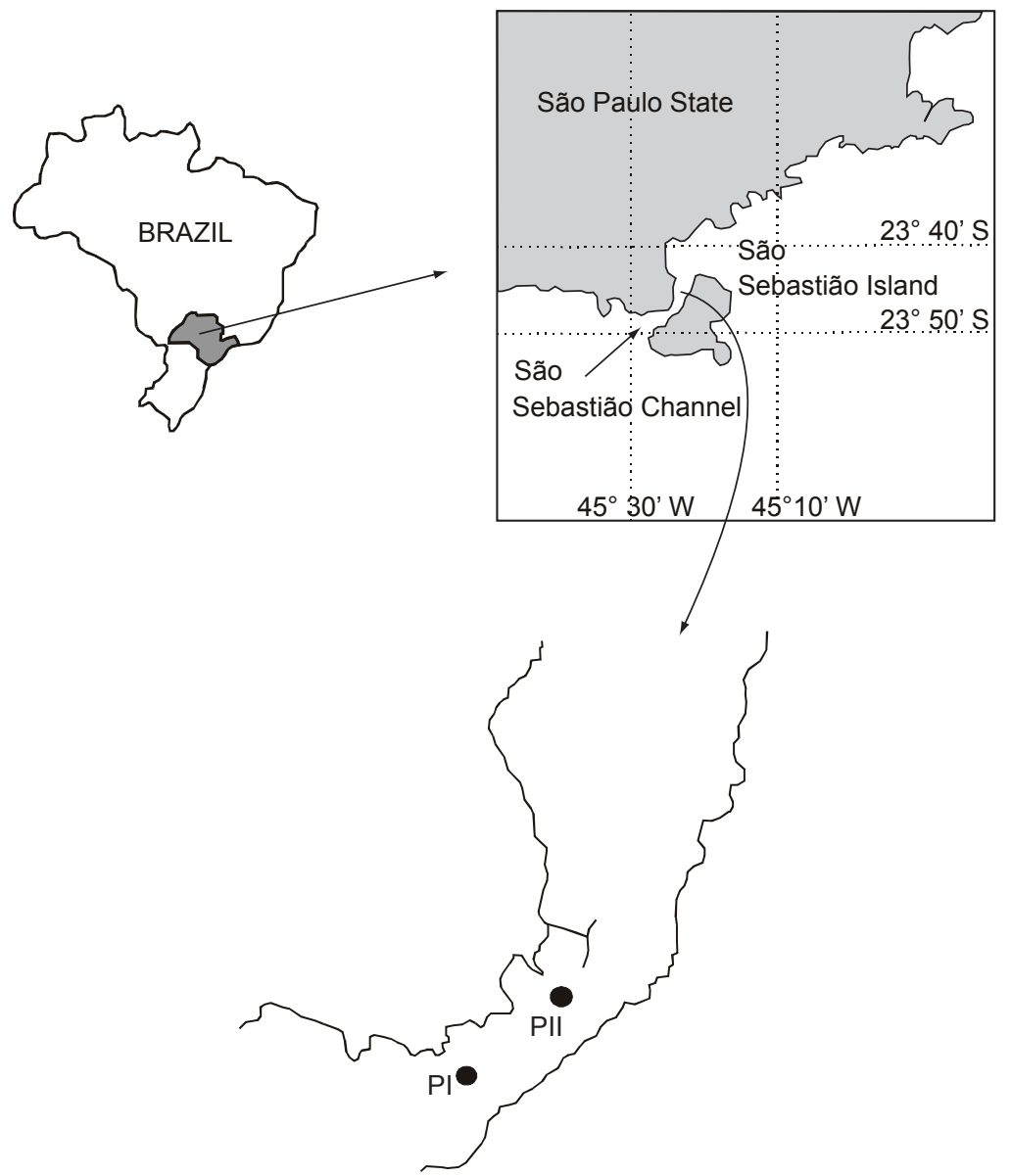

Fig. 1 - Map showing the sampling points in São Sebastião Channel.

found to occur in the SSC: one during summer and another in winter (values higher than 80 org. $\mathrm{L}^{-1}$ ). During the other annual periods, microzooplankton abundance was usually lower than 20 org. $\mathrm{L}^{-1}$.

The spatial distribution of microzooplankton in the SSC was quite similar at the two sampling points except for coastal copepod nauplii at P II, where a higher abundance of organisms such as Acartia lilljeborgi and Euterpina acutifrons was observed. The abundance of rotifer specimens was also considerably higher at sampling point II.

Protozoans, particularly tintinnids, were extremely abundant during summer and winter, and the same pattern was observed for copepod nauplii. Rotifers showed a random annual distribution. Over the study period, tintinnids predominated (overall mean of 52\%), followed by copepod nauplii (43.2\%) and rotifers (12\%). Compared with these organisms, the abundance of naked ciliates was significantly lower $(<6 \%)$ (Fig. 4).

A total of 31 tintinnid species representing twelve genera were identified. Species of the genus Tintinnopsis (T. campanula, T. lobiancoi, T. radix), in addition to Amphorellopsis acuta, Codonellopsis morchella, Eutintinnus tenuis, Favella ehrenbergii and Leprotintinnus nordqvisti, were particularly abundant, accounting, on average, for $>60 \%$ of the total tintinnid abundance.

Sticholonche zanclea, the single Protozoa species, occurred during nearly all the seasonal periods in the SSC, attaining significant densities in winter. Radiolarians were rare in the SSC and contributed very little to total microzooplankton densities (Table 1). 

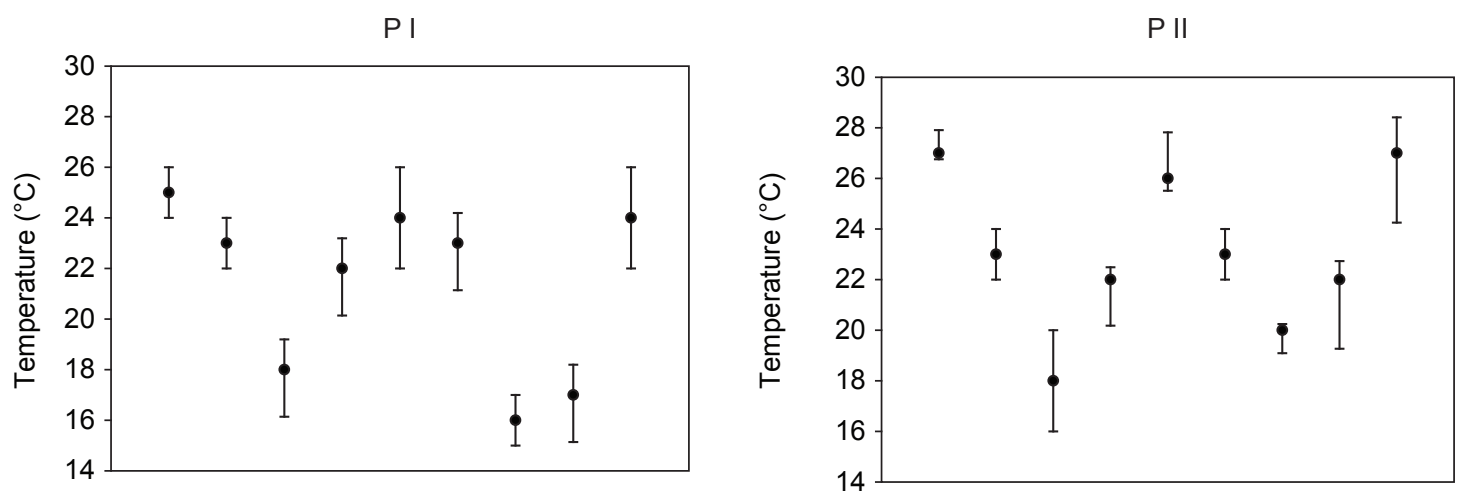

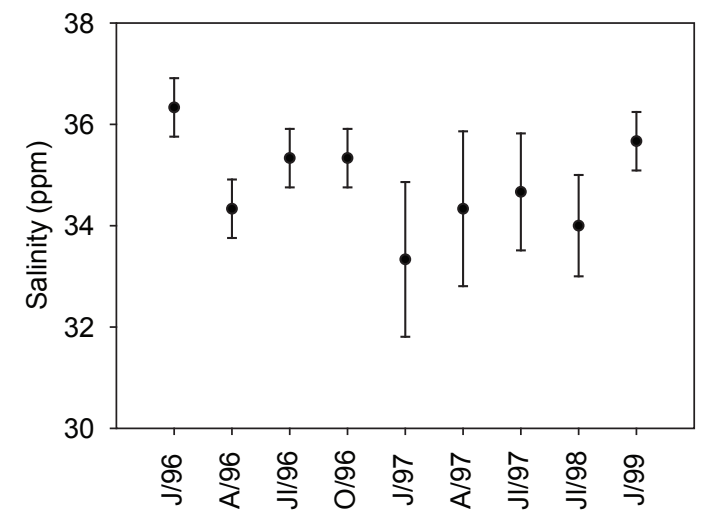

Sampling period

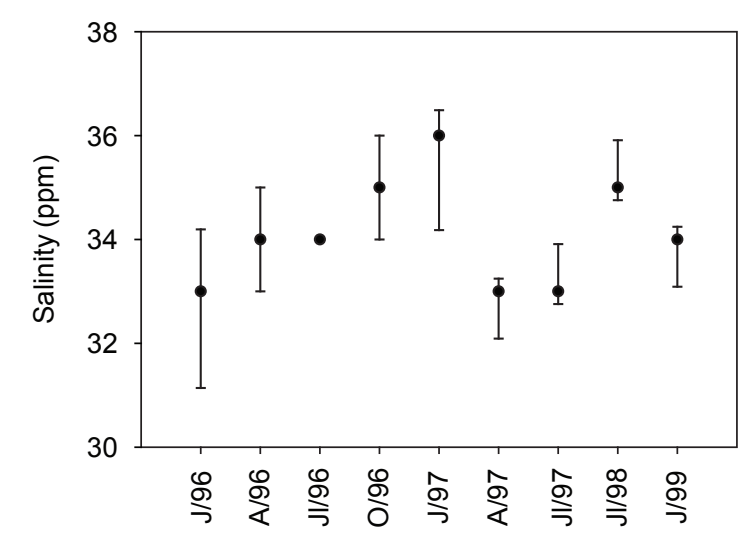

Sampling Period

Fig. 2 - Seasonal variations in surface and bottom temperatures $\left({ }^{\circ} \mathrm{C}\right)$ and salinity $(\%$ ), expressed as mean $(\bullet) \pm \operatorname{SD}($ vertical bars), respectively.

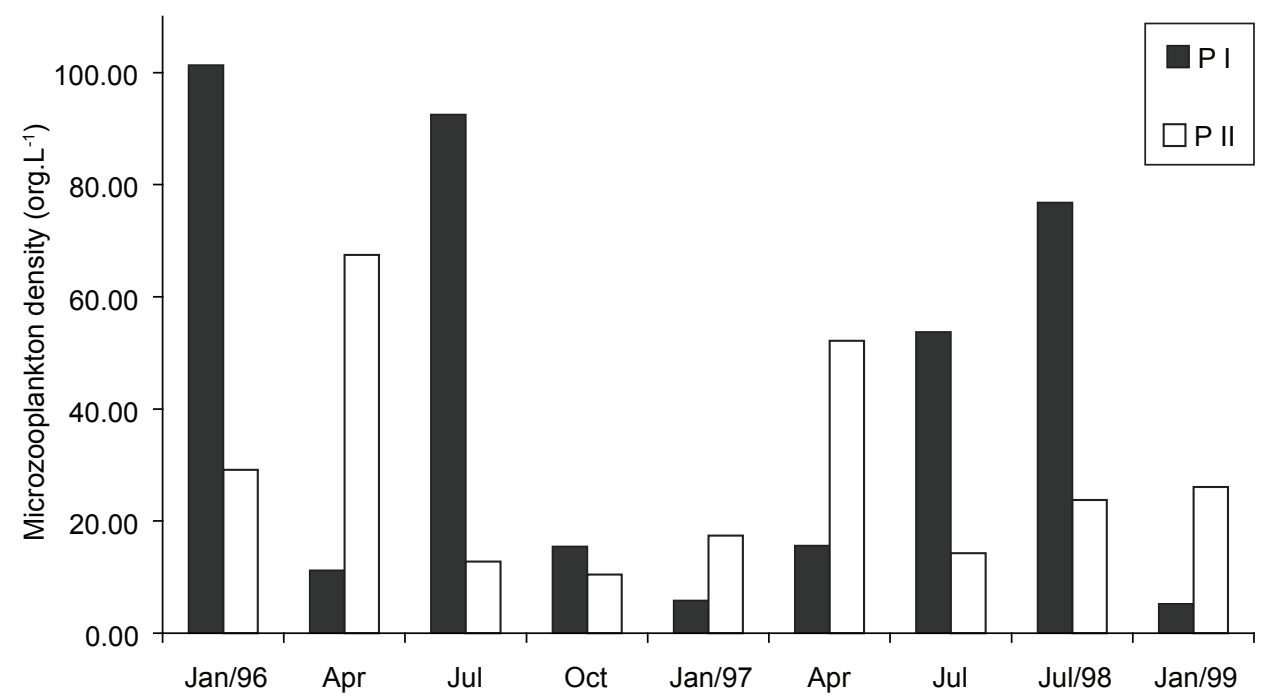

Fig. 3 - Seasonal variations in microzooplankton density. 
Copepod nauplii were abundant throughout the study, with a few exceptions. Nauplii of Acartia lilljeborgi, Oithona oswaldocruzi, Oithona sp, Oncaea sp, Paracalanus sp and Parvocalanus crassirostris were the most abundant forms. Rotifers showed a highly random quantitative distribution (usually $<10$ org. $\mathrm{L}^{-1}$ ), represented mainly by Brachionus sp, Euchlanis sp, Keratella tropica and Tricocherca marina.

\section{Microzooplankton occurrence in relation to environmental factors}

The influence of temperature and/or salinity on the numerical abundance of each taxon was analyzed by plotting the abundance data on a temperature and salinity chart (Fig. 5). Naked ciliates and tintinnids occurred at concentrations of $>50$ org. L $^{-1}$ over wide ranges of temperature (range 18-28 ${ }^{\circ} \mathrm{C}$ ) and salinity (31-36\%o) combinations. The conditions under which high concentrations (> 50 org. $\mathrm{L}^{-1}$ ) of copepod nauplii were observed were narrower ranges of temperature $\left(17-23{ }^{\circ} \mathrm{C}\right)$ and salinity (31-35\%o). Rotifers were also restricted to combinations of narrow temperature $\left(19-23{ }^{\circ} \mathrm{C}\right)$ and salinity (31-33\%o) ranges.
The influence of temperature and/or salinity was analyzed for 6 tintinnid species whose maximum concentrations reached $>100$ org.L $L^{-1}$ (Fig. 6). Most tintinnid species occurred on a distinctly seasonal basis. Amphorellopsis acuta, Eutintinnus tenuis and Favella ehrenbergi occurred in conditions of high temperature and salinity, while Tintinnopsis campanula, T. lobiancoi and T. radix were thermophilic, occurring primarily at temperatures of $<25^{\circ} \mathrm{C}$.

\section{DISCUSSION}

Distribution patterns for microzooplankton density and species composition in the SSC were similar to those reported for tropical coastal waters (Dolan \& Coats, 1990; Buskey, 1993; Verity, 1987; Godhantaram, 2001). Microzooplankton density is strongly affected by predation pressure, because microzooplankton is consumed by mesozooplankton and macrozooplankton (Porter et al., 1985; Stoecker \& Govoni, 1984). On the other hand, high densities of meso and macrozooplankton seem to enhance bacterial production and possibly also picoalgal growth, benefiting microzooplankton growth (Kivi et al., 1996). In the SSC, high values

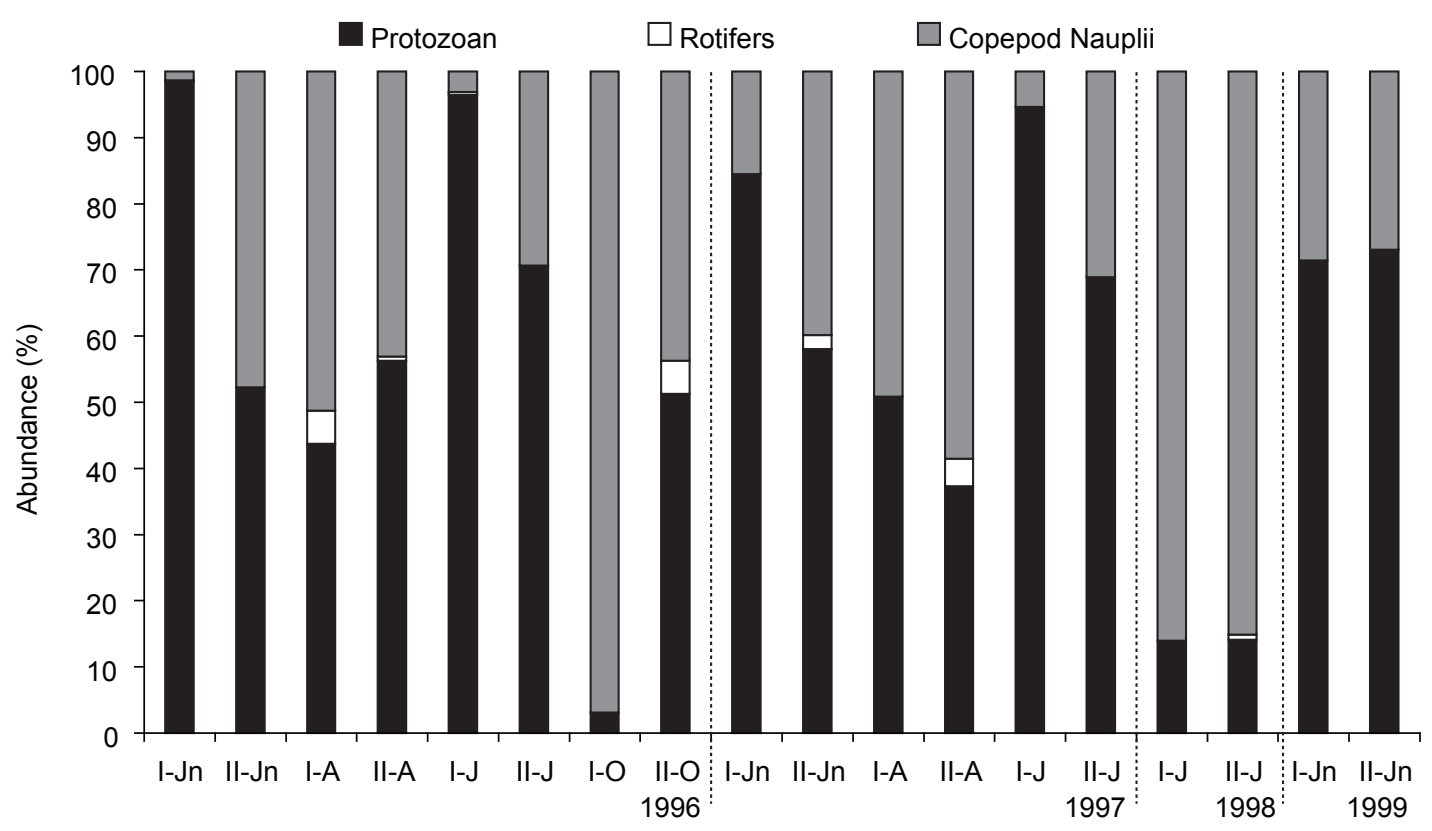

Fig. 4 - Seasonal variations in abundance of microzooplankton at each sampling point (I - point I; II - point II). $\mathrm{Jn}=$ January; A = April; $\mathrm{J}=\mathrm{July} ; \mathrm{O}=$ October. 
TABLE 1

Composition and occurrence of sampling station, month and annual abundance peak $\left(+<10,++10-50,+++>50\right.$ org. $\left.\mathrm{L}^{-1}\right)$.

\begin{tabular}{|c|c|c|c|}
\hline Name of Species & $\begin{array}{c}\text { Station, month and } \\
\text { annual abundance peak }\end{array}$ & Name of Species & $\begin{array}{c}\text { Station, month and } \\
\text { annual abundance peak }\end{array}$ \\
\hline Heliozoa & & T. lobiancoi & I (Jul/96) +++ \\
\hline Sticholonche zanclea & $\mathrm{I}(\operatorname{Jan} / 96)+++$ & T. radix & $\mathrm{I}(\mathrm{Jul} / 96)+++$ \\
\hline Radiolaria & & Tintinnopsis sp & II $(\mathrm{Apr} / 97)+++$ \\
\hline Acrosphaera spp & $\mathrm{I}(\mathrm{Jul} / 98)++$ & T. tocantinensis & $\mathrm{I}(\mathrm{Jul} / 97)+$ \\
\hline Actinoma spp & $\mathrm{I}(\mathrm{Jul} / 98)+$ & Naked Ciliates & \\
\hline Heliocostomella spp & $\mathrm{II}(\mathrm{Jan} / 97)+$ & Strombidium $\mathrm{sp}$ & $\mathrm{II}(\mathrm{Oct} / 96)+$ \\
\hline Heliodiscus asteriscus & $\mathrm{I}(\mathrm{Jan} / 96)+$ & Others & $\mathrm{I}(\operatorname{Jan} / 96)+++$ \\
\hline Hexacontium spp & $\mathrm{I}(\mathrm{Oct} / 96)+$ & Rotifera & \\
\hline Hexalonche spp & $\mathrm{I}(\mathrm{Jul} / 98)+$ & Brachionus sp & II $($ Apr/97) +++ \\
\hline Radiolaria (Spumellaria) & $\mathrm{I}(\mathrm{Jul} / 97)+$ & Euchlanis sp & II $($ Oct/96) ++ \\
\hline Radiolaria (others) & $\mathrm{II}(\mathrm{Apr} / 96)+$ & Keratella tropica & $\mathrm{I}(\mathrm{Apr} / 96)++$ \\
\hline Testacea & & Rotifers (others) & $\mathrm{I}(\mathrm{Jul} / 96)+$ \\
\hline Arcella vulgaris & II (Apr/96) + & Tricocherca marina & II $(\mathrm{Jul} / 98)+$ \\
\hline Centropyxis sp & $\mathrm{II}(\mathrm{Jul} / 96)+$ & Copepod Nauplii & \\
\hline Foraminifera & & Acartia lilljeborgi & II $($ Apr/97) +++ \\
\hline Foraminifera (others) & $\mathrm{II}(\mathrm{Jul} / 96)+$ & Calocalanus pavo & $\mathrm{I}(\mathrm{Apr} / 97)+$ \\
\hline Globorotalia sp & $\mathrm{II}(\mathrm{Apr} / 96)+$ & Calocalanus $\mathrm{sp}$ & $\mathrm{I}(\mathrm{Jul} / 98)+$ \\
\hline Tetromphalus bulloides & $\mathrm{I}(\mathrm{Apr} / 96)+$ & Canuellidae & II (Jul/97) ++ \\
\hline Tintinnida & & Centropages velificatus & $\mathrm{I}(\mathrm{Jul} / 98)+$ \\
\hline Amphorellopsis acuta & II $(\operatorname{Jan} / 97)+++$ & Clausocalanus sp & $\mathrm{I}(\mathrm{Oct} / 96)+$ \\
\hline Amphorides amphora & $\mathrm{I}(\mathrm{Jan} / 97)+$ & Corycaeus sp & $\mathrm{I}(\mathrm{Jul} / 98)++$ \\
\hline Amphorellopsis sp & $\mathrm{I}(\mathrm{Oct} / 96)+$ & Ctenocalanus sp & $\mathrm{I}(\mathrm{Apr} / 97)++$ \\
\hline Amphorides amphora & $\mathrm{I}(\mathrm{Jan} / 99)++$ & Ctenocalanus vanus & $\mathrm{I}(\mathrm{Apr} / 96)+$ \\
\hline Codonella $\mathrm{sp}$ & $\mathrm{I}(\mathrm{Jul} / 96)+$ & Eucalanus pileatus & $\mathrm{I}(\mathrm{Jul} / 98)++$ \\
\hline Codonellopsis morchella & II $($ Apr/96) +++ & Eucalanus sp & $\mathrm{I}(\mathrm{Jan} / 96)+$ \\
\hline Codonellopsis sp & $\mathrm{I}(\mathrm{Jul} / 96)++$ & Euterpina acutifrons & II $($ Apr/96) ++ \\
\hline Coxliella annulata & II $($ Apr/97) ++ & Harpacticoida & II $(\operatorname{Jan} / 96)+$ \\
\hline C. intermedia & $\mathrm{II}(\mathrm{Jul} / 96)+$ & Longipedia $\mathrm{sp}$ & II $(J a n / 96)+++$ \\
\hline C. laciniosa & II $(\mathrm{Apr} / 97)++$ & Microsetella rosea & II (Apr/96) + \\
\hline C. minor & $\mathrm{I}(\mathrm{Apr} / 96)+$ & Microsetella $\mathrm{sp}$ & $\mathrm{II}(\mathrm{Jul} / 98)+$ \\
\hline Coxiliella $\mathrm{sp}$ & $\mathrm{I}(\mathrm{Jan} / 99)+$ & Oithona nana & $\mathrm{II}(\mathrm{Apr} / 96)+$ \\
\hline Dadayella pachytoechus & II (Apr/96) ++ & O. oswaldocruzi & $\mathrm{I}(\mathrm{Jul} / 98)+++$ \\
\hline Dictyocysta $\mathrm{sp}$ & $\mathrm{I}(\mathrm{Jul} / 96)++$ & O. simplex & $\mathrm{I}(\mathrm{Apr} / 96)+$ \\
\hline Eutintinnus similis & $\mathrm{I}(\mathrm{Jul} / 97)+$ & Oithona $\mathrm{sp}$ & II (Jul/98) +++ \\
\hline Eutintinnus sp & II $(\operatorname{Jan} / 99)+++$ & Oncaea sp & I (Jul/98) +++ \\
\hline E. tenuis & II $(\operatorname{Jan} / 99)+++$ & Paracalanus aculeatus & $\mathrm{I}(\mathrm{Jul} / 97)+$ \\
\hline Favella ehrenbergi & I $(\operatorname{Jan} / 96)+++$ & Paracalanus $\mathrm{sp}$ & I (Jul/98) +++ \\
\hline Leprotintinnus nordqvisti & II $($ Apr/96) +++ & Parvocalanus crassirostris & II (Apr/96) +++ \\
\hline Rhabdonellopsis sp & $\mathrm{I}(\mathrm{Jul} / 97)+$ & Pleuromamma $\mathrm{sp}$ & $\mathrm{I}(\mathrm{Apr} / 96)+$ \\
\hline Stylicauda platensis & $\mathrm{II}(\mathrm{Oct} / 96)+$ & Pontellopsis sp & $\mathrm{I}(\mathrm{Apr} / 96)+$ \\
\hline Tintinnopsis amphistoma & $\mathrm{I}(\mathrm{Jul} / 97)+$ & Pseudodiaptomus acutus & $\mathrm{I}(\mathrm{Jul} / 96)+$ \\
\hline T. aperta & $\mathrm{II}(\mathrm{Jul} / 97)+$ & Pseudodiaptomus $\mathrm{sp}$ & $\mathrm{I}(\mathrm{Jul} / 98)++$ \\
\hline T. campanula & I (Jul/96) +++ & Temora stylifera & I (Jul/98) ++ \\
\hline T. gracilis & $\mathrm{I}(\mathrm{Jul} / 96)+$ & T. turbinata & II $(\operatorname{Jan} / 96)++$ \\
\hline T. lata (?) & I (Jul/97) + & & \\
\hline T. levigata & $\mathrm{I}(\mathrm{Jul} / 98)+$ & & \\
\hline
\end{tabular}



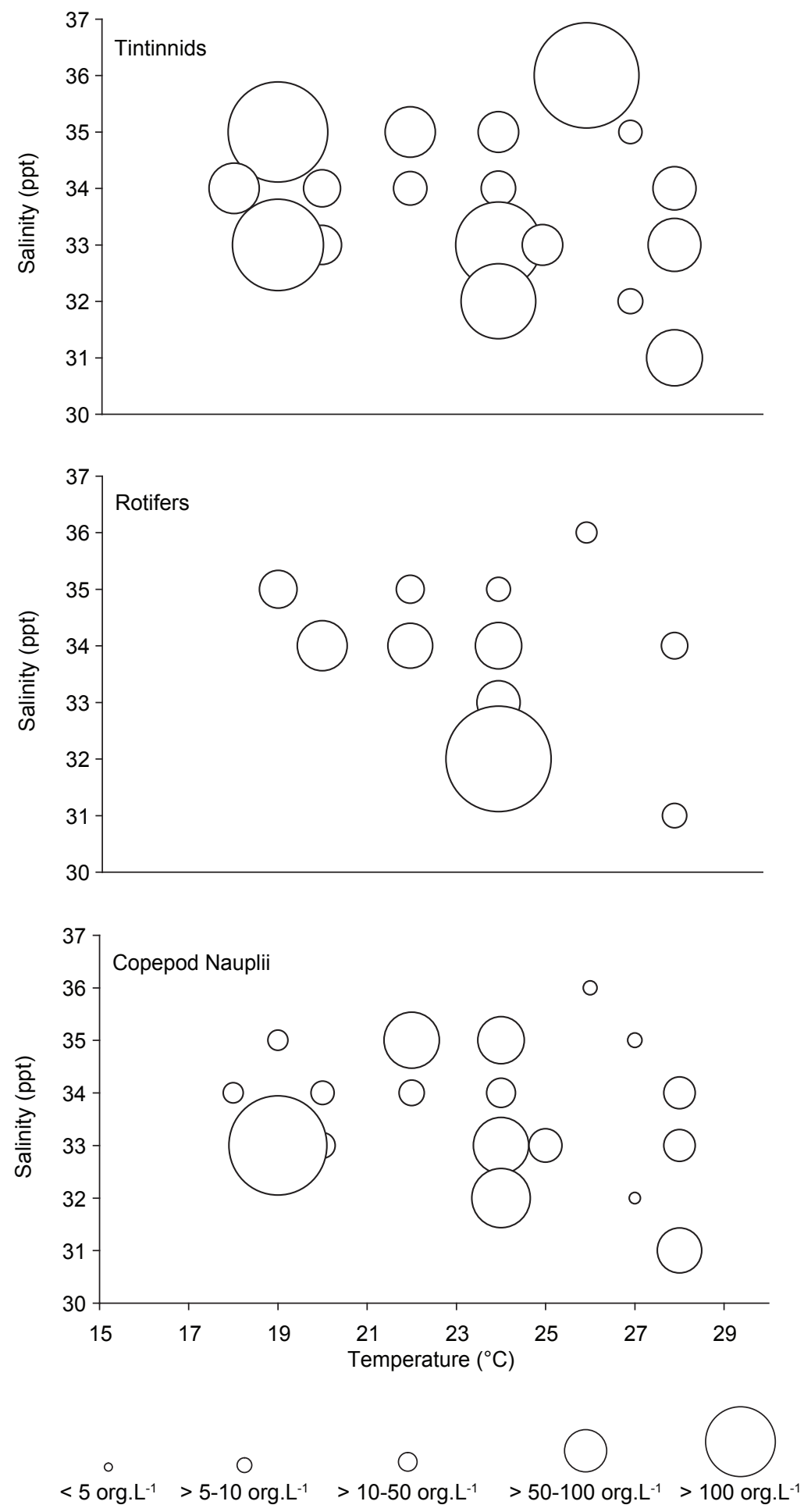

Fig. 5 - Abundance-temperature-salinity diagram for microzooplankton. 

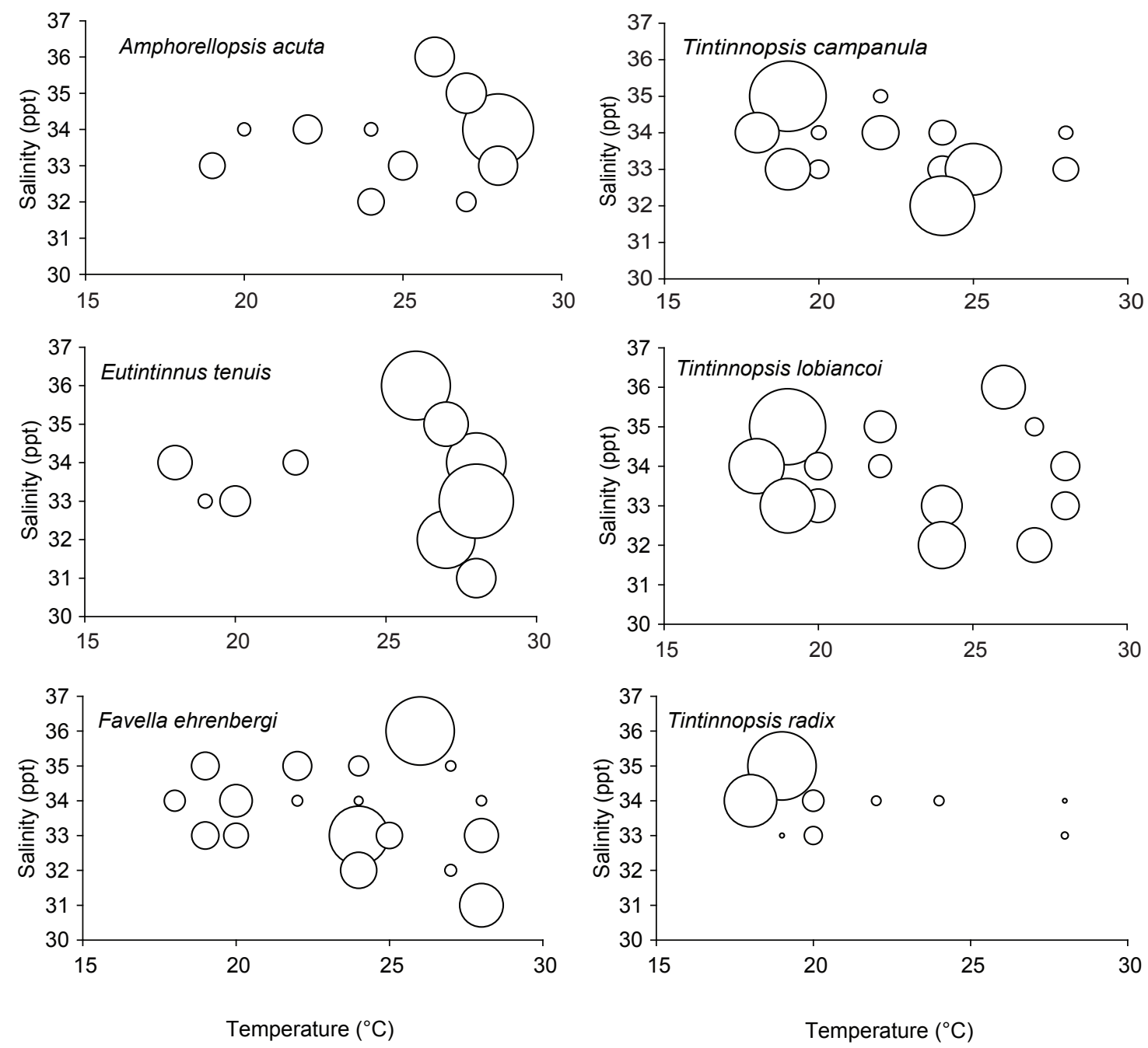

Fig. 6 - Abundance-temperature-salinity diagram for tintinnids occurring at densities of $>50$ org.L. ${ }^{-1}$.

of meso- and macrozooplankton, which may represent an important element in the control of microzooplanktonic density, were reported by $\mathrm{De} \mathrm{La}$ Rocha (1998) and Gianesella-Galvão et al., (1997).

In general, and particularly in tropical waters, the microzooplankton distribution and abundance varies considerably due to seasonal environmental fluctuations (Godhantaram, 2002). Two seasonal peaks of microzooplankton abundance were found to occur in the SSC: one peak in summer and another in winter. Very peculiar oceanographic conditions occur in the SSC, which is under the domain of three distinct water masses: the Coastal Waters $\left(\mathrm{CW}-\mathrm{T}>20^{\circ} \mathrm{C} ; \mathrm{S}<35 \%\right.$ ), the South Atlantic
Central Waters (SACW $-\mathrm{T}<20^{\circ} \mathrm{C} ; \mathrm{S}>35 \%$ ) and the Tropical Waters (TW $-\mathrm{T}>20^{\circ} \mathrm{C} ; \mathrm{S}>36 \%$ ). In the SSC, the influence of $\mathrm{CW}$ is particularly evident. In summer, due to the coastal upwelling phenomenon in the region between Cabo Frio and Ilha Grande (Rio de Janeiro State), SACW intrudes into the SSC, causing a marked drop in water temperature and enrichment by nutrients, with an increase in the primary and secondary production (Aidar et al., 1993).

The higher densities of microzooplankton, particularly tintinnids, in summer may be attributed to a combination of temperature and salinity conditions and chlorophyll- $a$ concentrations, which 
are often considered the most important factors in the acceleration of their growth rate (Relevante \& Gilmartin, 1983; Sanders, 1987). In winter, with the underwelling of the SACW, the phytoplanktonic populations associated with oligotrophic water masses predominate in the SSC, especially nanoplanktonic phytoflagellates, which are largely consumed by the microzooplankton (Pierce \& Turner, 1992). Thus, it may be concluded that the water masses play a crucial role in the seasonal dynamics of microzooplankton assemblages in the São Sebastião Channel.

Most tintinnid species appeared on a remarkably seasonal basis, with the eurythermal species Amphorellopsis acuta, Eutintinnus tenuis and Favella ehrenbergii standing out in particular. The winter peak was attributed mainly to Tintinnopsis campanula, T. lobiancoi and T. radix, indicating their thermophilic nature.

Sticholonche zanclea was also a protozoan with very significant densities in the SSC, occurring during all the seasons, and was thus considered a resident species of the area. Further studies on the spatial distribution and temporal dynamics of this protozoan should be conducted, since this species seems to play a crucial role in the trophic planktonic structure of the SSC, as a food item largely consumed by the local meso- and macrozooplanktonic assemblages (Eskinazi-Sant'Anna, 2000).

Naked ciliates showed very low abundance rates in the present study, contrasting with the pattern usually described for tropical coastal waters (Leakey et al., 1992; Pierce \& Turner, 1993). Although the methodological approach in the present investigation is adequate for the quantitative study of naked ciliates, further studies are necessary in order to better describe the quantitative pattern of naked ciliates in the SSC.

The occurrence of rotifers and some nauplii of coastal copepod species like Acartia lilljeborgi and Oithona oswaldocruzi was more marked at point II, indicating the preference of these organisms for lower salinity. Lower salinity values at sampling point II indicate the influence of continental waters in this coastal region of the SSC. However, the composition of the microzooplanktonic assemblages did not exhibit significant spatial differences between point I and
II, with coastal-marine species being the most abundant in both points.

One of the characteristic features in this study was the relatively large contribution of copepod nauplii, which was attributed to high concentrations of older stages of copepods in the SSC (Eskinazi-Sant'Anna, 2000). According to Björnberg (1986), copepod nauplii are usually underestimated due to methodological difficulties and morphotype identification. However, when appropriately analyzed, copepod nauplii can surpass, in terms of density, the copepodite and adult forms, and be considered a crucial intermediary between the classical food web and the microbial web (Roff et al., 1995).

Given the short generation times of microzooplankton, they can respond rapidly to changes in food availability and have a significant impact on phytoplankton through grazing. Estimates of the grazing impact of microzooplankton on phytoplankton range from 5 to $100 \%$ (Gifford, 1988; Capriulo et al., 1991). Although no direct measurement was taken of microzooplankton grazing rates, given their abundance and the fact that most of the chlorophyll and primary production in the SSC is in the nanoplankton (Gaeta et al., 1995), microzooplankton must play a critical role in secondary production of the water column in the SSC.

\section{REFERENCES}

AIDAR, E., GAETA, S. A., GIANESELLA-GALVÃO, S. M. F., KUTNER, M. B. B. \& TEIXEIRA, C., 1993, Ecossistema costeiro subtropical: nutrientes dissolvidos, fitoplâncton e clorofila- $a$ e suas relações com as condições oceanográficas na região de Ubatuba, SP. Publção. esp. Inst. ocenogr., S. Paulo, 10: 9-43.

ALDER, V. A., 1999, Tintinnoinea. In: D. Boltovskoy (ed.), South Atlantic Zooplankton. Backhuys Publishers, Leiden.

BALECH, E., 1971, Microplancton del Atlantico Ecuatorial Oeste (Equalant I). Ser. Hidrogr. Nav. Buenos Aires, 654: 1-103.

BJÖRNBERG, T. K. S., 1986, The rejected nauplius: a commentary. Syllogeus, 58: 232-236.

BJÖRNBERG, T. K. S., LOPES, R. M. \& BJÖRNBERG, M. H. G. C., 1994, Chave para a identificação de náuplios de copépodos planctônicos marinhos do Atlântico SulOcidental. Náuplius, 2: 1-16.

BOLTOVSKOY, D., 1999, Radiolaria. In: D. Boltovskoy (ed.), South Atlantic Zooplankton. Backhuys Publishers, Leiden.

BURKIL, P. H., MANTOURA, R. F. C., LLEWELLYN, C. A. \& OWENS, N. J. P., 1987, Microzooplankton grazing and 
selectivity of phytoplankton in coastal waters. Mar. Biol., 93: 581-590.

BUSKEY, E. J., 1993, Annual pattern of micro- and mesozooplankton abundance and biomass in a subtropical estuary. J. Plankton Res., 15: 907-924.

CAPRIULO, G. M., SHERR, E. B. \& SHERR, B. F., 1991, Trophic behavior and related community feeding activities of heterotrophic marine protists. In: P. C. Reid, C. M. Turley, \& P. H. Burkill (eds.), Protozoa and their role in Marine processes. NATO ASI Ser. G, $25^{\circ}$ vol., Springer-Verlag, New York.

DE LA ROCHA, C. L., 1998, Variação temporal da comunidade zooplanctônica e produção anual do copépodo Acartia lilljeborgi na enseada da Praia do Segredo (São Sebastião - SP). Dissertação de Mestrado, Centro de Biologia Marinha, Universidade de São Paulo, 113p.

DOLAN, J. R. \& COATS, D. W., 1990, Seasonal abundance of planktonic ciliates and microflagellates in mesohaline Chesapeake Bay waters. Estuar. Coast. Shelf Sci., 31: 157-175.

ESKINAZI-SANT'ANNA, E. M. E., 2000, Estudo da dieta natural de Parvocalanus crassirostris, Paracalanus quasimodo, Temora stylifera e Temora turbinata (Copepoda, Calanoida), no Canal de São Sebastião (Brasil-SP). Tese de Doutorado, Centro de Biologia Marinha, Universidade de São Paulo, 317p.

FENCHEL, T., 1987, Ecology of Protozoa. The Biology of Free-Living Phagotrophic Protists. Springer-Verlag, Berlin, 197p.

FERNANDES, L. F., 2004a, Tintininos (Ciliophora - Subordem Tintinnina) de águas subtropicais na região Sueste-Sul do Brasil ( $23^{\circ} \mathrm{S}-34^{\circ} \mathrm{S}$ e $\left.37^{\circ} \mathrm{W}-52^{\circ} \mathrm{W}\right)$ I. Famílias Codonellidae, Codonellopsidae, Coxliellidae, Cyttarocyllidae, Epiplocylidae, Petalotrichidae, Ptychocylidae, Tintinnididae e Undellidae. Rev. Brasil. Zool., 21: 551-576.

FERNANDES, L. F., 2004b, Tintininos (Ciliophora - Subordem Tintinnina) de águas subtropicais na região Sueste-Sul do Brasil $\left(23^{\circ} \mathrm{S}-34^{\circ} \mathrm{S}\right.$ e $\left.37^{\circ} \mathrm{W}-52^{\circ} \mathrm{W}\right)$. II. Famílias Dictyocystidae, Rhabdonellidae, Tintinnidae e Xystonellidae. Rev. Brasil. Zool., 21: 605-628.

GAETA, S. A., TEIXEIRA, C., ABE, D. S., LOPES, R. M. \& SUSINI, S. M., 1995, Size-fractionation of primary production and phytoplankton biomass on inshore waters of the Ubatuba region, Brazil. Publção. Esp. Inst. Ocenogr., S. Paulo, 11: 153-162.

GIANESELLA-GALVÃO, S. M. F., AIDAR, E., VEGA-PÉREZ, L.A.\&SALDANHA-CORRÊA, F. M.P., 1997, Distribuição do plâncton na região costeira de São Sebastião. Relat. Téc. Inst. Oceanogr., 41: 5-14.

GIFFORD, D. J., 1988, Impact of grazing by microzooplankton in the Northwest Arm of Halifax Harbour, Nova Scotia. Mar. Ecol. Prog. Ser., 47: 249-258.

GIFFORD, D. J., 1991, The protozoan-metazoan trophic link in pelagic ecosystems. J. Protozool., 38: 81-86.

GODHANTARAMAN, N., 2001, Seasonal variations in taxonomic composition, abundance and food web relationship of microzooplankton in estuarine and mangrove waters, Parangipettai region, southeast coast of India. Indian $J$. Mar. Sci., 30: 151-160.
GODHANTARAMAN, N., 2002, Seasonal variations in species composition, abundance, biomass and estimated production rates of tintinnids at tropical estuarine and mangrove waters, Parangipettai, southeast coast of India. J. Mar. Sci., 36: 161-171.

GODHANTARAMAN, N. \& UYE, S., 2001, Geographical variations in abundance, biomass and trophodynamic role of microzooplankton across and inshore-offshore gradient in the Inland Sea of Japan and adjacent Pacific Ocean. Plankton Biol. Ecol., 48: 19-27.

KIVI, K., KUOSA, H. \& TANSKANEN, S., 1996, An experimental study on the role of crustacean and microprotozoan grazers in the planktonic food web. Mar. Ecol. Prog. Ser. 136: 59-68.

KOSTE, W., 1978, Rotatoria. Die Rädertiere Mitteleuropas. Gebrüder Borntraeger, Berlin.

LEAKEY, R. J. G., BURKILL, P. H. \& SLEIGH, M. A., 1992, Planktonic ciliates in Southampton water: abundance, biomass, production, and role in pelagic carbon flow. Mar. Biol., 114: 67-83.

LINN, D. H., MONTAGNES, D. J. S., SALE, T., GILRON, G. L. \& STROM, S. L. 1991. A reassessment of the genus Strombidinopdis (Ciliophora, Choreotrichida) with descriptions of four new planktonic species and remarks on its taxonomy and phylogeny. J. Mar. Biol. Assoc. U.K., 71: 597-612.

LINLEY, E. A. S., NEWELL, R. C. \& LUCAS, M. I., 1983, Quantitative relationships between phytoplankton, bacteria and heterotrophic microflagellates in shelf waters. Mar. Ecol. Prog. Ser., 12: 77-91.

NOGUEIRA-PARANHOS, J. D., 1990, Taxonomia e ecologia dos Tintinnina em um trecho da plataforma de Pernambuco (Brasil). Dissertação de Mestrado, Departamento de Oceanografia, Universidade Federal de Pernambuco, 149p.

PETZ, W., 1999, Ciliophora. In: D. Boltovskoy (ed.), South Atlantic Zooplankton. Backhuys Publishers, Leiden.

PIERCE, R. W. \& TURNER, J. T., 1992, Ecology of planktonic ciliates in marine food webs. Rev. Aquat. Sci., 6: 139-181.

PIERCE, R. W. \& TURNER, J. T., 1993, Global biogeography of marine tintinnids. Mar. Ecol. Prog. Ser., 94: 11-26.

POMPEU, M., 1998, Microzooplâncton-Tintinnina da região de Abrolhos $\left(16^{\circ}\right.$ a $21^{\circ}$ e $36^{\circ}$ a $\left.41^{\circ} \mathrm{W}\right)$. Dissertação de Mestrado, Instituto Oceanográfico, Universidade de São Paulo, 245p.

PORTER, K. G., SHERR, E. B., SHERR, B. F., PACE, M. \& SANDERS, R. W., 1985, Protozoa in planktonic food webs. J. Protozool., 32: 409-415.

RELEVANTE, N., \& GILMARTIN, M., 1983, The microzooplankton distribution in the northern Adriatic Sea with emphasis on the importance of ciliated protozoans. Oceanol. Acta, 6: 407-417.

RELEVANTE, N., GILMARTIN, M. \& SMODLAKA, N., 1985, The effects of Po River induced eutrophication on the distribution and community structure of ciliated protozoan and micrometazoan populations in the northern Adriatic Sea. J. Plankton Res., 7: 461-471.

ROFF, J. C., TURNER, J. T., WEBBER, M. K \& HOPCROFF, R. R., 1995, Bacterivory by tropical copepod nauplii: 
extent and possible significance. Aquat. Microbiol. Ecol., 9: $165-175$.

SANDERS, R. W., 1987, Tintinnids and other microzooplankton seasonal distribution and relationship to resources and hydrography in a Maine estuary. J. Plankton Res., 9: 65-77.

SASSI, R. \& MELO, G., 1989, Hyaline Tintinnina (ProtozoaCiliophora-Oligotrichida) from northeast Brazilian coastal reefs. Bolm. Inst. Oceanogr. S. Paulo, 37: 59-74.

SOUTO, S., 1981, Tintinnina. In: D. Boltovskoy (ed.), Atlas del zooplancton del Atlantico sudoccidental y métodos de trabajo con el zooplancton marino. INIDEP, Mar del Plata.
STOECKER, D. K. \& EGLOFF, D. A., 1987, Predation by Acartia tonsa Dana on planktonic ciliates and rotifers. J. Expl. Mar. Biol. Ecol., 110: 53-68.

STOECKER, D. K. \& GOVONI, J. J., 1984, Food selection by young larval gulf menhaden (Brevoortia patronus). Mar. Biol., 80: 299-306.

VERITY, P. G., 1987, Abundance, community composition, size distribution, and production rates of tintinnids in Narragansett Bay, Rhode Island. Estuar. Coast. Shelf Sci. 24: 671-690. 